\title{
Amenity Migration and Public Lands: Rise of the Protected Areas
}

\author{
Evan Hjerpe $^{1} \cdot$ Anwar Hussain $^{1} \cdot$ Thomas Holmes $^{2}$
}

Received: 4 October 2019 / Accepted: 31 March 2020 / Published online: 27 April 2020

(c) Springer Science+Business Media, LLC, part of Springer Nature 2020

\begin{abstract}
Rural amenity migration, or the relocation for quality of life purposes as opposed to monetary enhancement, has been occurring for decades and has been particularly pronounced in the American West where the phenomenon peaked in the 1990s. Researchers have illustrated that some places are more attractive for migrants than others and that certain regional amenities hold considerable influence on where migrants relocate. Increased migration levels typically result in increased economic growth indicators, making amenity migration an attractive rural development strategy. But comprehensive econometric analysis focused on amenity migration in the American West has been lacking. To address this, we conducted an econometric analysis of attributes that influenced migration to rural Western counties from 1980 to 2010. Over 20 potential amenity supply categories were collated for 356 rural counties from 11 Western states, with a focus on public lands. Descriptive statistics and OLS regressions were estimated and interpreted. Traditional amenities of climate, water area, and regional access were highly associated with migration levels, while designated natural amenities of Wilderness and National Monuments were the most influential public lands for migration to rural Western counties. Farming and oil and gas dependency were negatively associated with migration levels. Increasing the amount of protected areas, and branding campaigns based on natural amenities, can be a critical development strategy for rural communities.
\end{abstract}

Keywords Amenity migration · Protected areas · Outdoor recreation · Public lands · Designated natural amenity

\section{Introduction}

During the past three decades, rural communities in the American West have experienced significant economic restructuring, transitioning from extractive-based industries toward service-based economies (Beyers and Nelson 2000). A major impetus for economic restructuring in the Western U.S. (hereafter, the West) has been amenity migration, a phenomenon in which people relocate to communities for physical and social amenities derived from an abundance of desired ecosystem services as opposed to simply following employment opportunities (Power 1996, Rudzitis 1999; Rasker 2006). These amenity migrants include footloose entrepreneurs, retirees, and people willing to trade income for a higher quality of life. While increased migration rates

Evan Hjerpe

evan@conservationecon.org

Conservation Economics Institute, Twin Falls, ID, USA

2 U.S. Forest Service, Southern Research Station, Asheville, NC, USA and service-related economic indicators for rural Western regions have been well documented, questions remain concerning the role that public lands have played in amenity migration.

The majority of federal lands are in the West, meaning that many of the most spectacular landscapes for outdoor recreation and nature tourism, two primary drivers of natural amenity migration, are part of the overall Western public lands portfolio. Indeed, public lands have consistently been shown to play a role in attracting amenity migrants (e.g., Rudzitis and Johnson 2000; Lorah and Southwick 2003), but the majority of research has aggregated public land types and most studies have only investigated relationships using descriptive statistics and simple correlations. There has been little econometric investigation of the type of public lands (i.e., lands used for grazing/ logging versus protected public lands such as Wilderness) that have had the greatest influence on amenity migration and overall economic restructuring of the rural West.

Population growth in rural counties is generally considered to be desirable because it is associated with improvements in standard economic indicators of wellbeing such as employment, per capita income, and regional 
tax revenues (Deller et al. 2001). ${ }^{1}$ While population and economic growth in rural communities is not without its problems (see for example, Howe et al. 1997; Green 2001; Abrams et al. 2012), virtually all rural county officials would prefer growth over population contraction. County commissioners and planners have been quick to articulate the economic benefits associated with export products such as timber and minerals. What has not been as clearly promoted is the suite of opportunities provided by public lands that can position a region to capitalize on the provision of natural assets which, through the process of amenity migration, attract businesses and transfer income. This is largely due to a suite of conceptual and empirical challenges faced when quantifying the linkages between quality of life enhancements derived from local access to public lands and standard economic indicators (Marcouiller and Deller 1996). Consequently, provision of better information detailing the characteristics of public lands most influential in modulating patterns of amenity migration could raise the awareness of policymakers and regional leaders regarding the benefits of alternative pathways for economic growth.

The amenity migration phenomenon in the rural West, and attendant growth in economic activity, peaked in the 1990s and has greatly diminished during the last few years (Rickman and Wang 2018). The three decades from 1980 to 2010 bracket a period encompassing the growth-decline dynamics of the amenity migration phenomenon, suggesting that this is an ideal time for retrospective analysis. Researchers have indicated that key components that would contribute to more comprehensive analysis of this phenomena have been missing such as longitudinal, ex post analysis of amenity migration (Kruger et al. 2008), expansion beyond single dimensional amenity attributes (Deller et al. 2001), and clarifying amenity impacts on communities (Green et al. 2005).

To address these gaps in the literature, we conducted an econometric analysis of amenity migration and public lands from 1980 to 2010 in the rural West. The specific objective of this study is to determine why some rural Western counties have been more successful than others in attracting amenity migrants. To do this, we specified an econometric model that identifies the most important attributes of a region that account for rural amenity migration. A comprehensive county-level dataset was compiled that included numerous categories of public lands, geographic variables, climatic variables, and some of the most influential built amenities that support natural amenities. Public lands were

\footnotetext{
${ }^{1}$ One noted exception we are aware of is the effects study of the Northwest Forest Plan ecosystem conservation in the Pacific Northwest by Eichman et al. (2010), which found increased net migration but decreased employment growth. However, this study included metro and nonmetro counties and focused on a time period with rapidly declining timber production.
}

delineated into protected areas including Wilderness Areas, National Monuments, National Parks, Wilderness Study Areas (WSAs), Wild and Scenic Rivers, and Inventoried Roadless Areas. Public lands were also categorized by the managing federal agency including U.S. Forest Service (USFS), Bureau of Land Management (BLM), National Park Service (NPS), and U.S. Fish and Wildlife Service (USFWS). This level of detail has not been previously analyzed in the rural West.

\section{Literature Review and Background}

Compared with the eastern U.S., the rural West was developed and populated quite recently, transitioning from more sparsely populated native American tribes to industrialized development in the late 1800s. For a century following the completion and connection of the West with the transcontinental railroad in 1869 , the rural West developed economies strictly driven by resource extraction, ranching, and agriculture. Federal lands in the West during this era played a large role in supporting extractive industries and ranching. Agencies such as the USFS and the BLM facilitated logging, mining, and grazing on vast tracts of public land, while attempting to improve the scientific management of natural resources on those lands.

While a few iconic nature preserves such as Yellowstone, Sequoia, and Yosemite were protected as National Parks starting in the 1870s, it was the advent of Wilderness legislation in 1964 that protected a substantial portion of Western federal lands and placed limits on the extraction that had been sweeping public lands. By the 1980s, greater global markets for natural resources helped lower the real price of raw materials, which started to lessen the importance of extractive industries in rural areas (Galston and Baehler 1995). These resource dependent communities were subject to powerful external, global capitalist interests that helped determine local economic opportunities (Robbins 1994). In the 1990s, global timber markets and technological advances combined with new conservation measures on public lands (e.g., spotted owl protections) to dramatically reduce logging and timber harvests in the rural West (Cook 1995; Charnley et al. 2008). While extractive industries were decreasing in importance, service-based industries in rural areas were on the rise (Power 1996; Mather 2001). These service sectors included tourism and recreation services along with high-wage service sectors such as financial, medical, and information industries.

Ultimately, the rural West experienced a dramatic economic restructuring during the late 20th century, shifting from resource development to service-dominated industries (Shumway and Otterstrom 2001). Concurrent with the economic restructuring were noticeable migration trends to 
rural Western areas (Cromartie and Wardwell 1999). While international competition, mechanization, and evolving public lands policies were blamed for much of the economic restructuring, some in the West suggested that something else was at play. Western regional economists showed that people were attracted to natural amenities and protected lands and were placing environmental quality and outdoor recreation opportunities ahead of traditional employment and labor opportunities (Power 1991; Rasker 1993). Geographers were also illustrating the importance of natural amenities through surveys of rural populations (e.g., Rudzitis and Johansen 1991; Rudzitis and Streatfeild 1993; Rudzitis 1996), indicating the strong role of protected lands in attracting and retaining amenity migrants.

While amenities have long played a role in regional growth (e.g., Ullman 1954), ${ }^{2}$ formal economic models incorporating amenities as influencing variables on net migration rates were slow to develop. The traditional neoclassical migration model (e.g., Sjaastad 1962) assumed that people relocated primarily to gain employment and to increase their income. While transaction costs and nonmarket attributes associated with relocation tradeoffs were acknowledged, they were not endogenized into migration models due to the difficulty in determining nonmarket benefits and due to the assumed minimal role that they played in migration decisions. Modeling by Graves and Linneman (1979) changed the calculus by explicitly including some nonmarket attributes, such as amenities, into the migration equations. Roback (1982) further incorporated amenities into the relocation tradeoff model, as did by Carlino and Mills (1987).

Amenities are site-specific qualities that make a place more or less attractive for living and work and are by definition noncommercial goods and services, or public goods-that is, amenities cannot be purchased individually in formal markets (Power 2005). Amenities tend to be nonproducible, irreversible, subject to high income elasticity of demand, and regionally non-tradeable (Marcouiller and Clendenning 2005). Amenities have varying characteristics and can be broadly categorized as natural, built, social, or cultural (Power 2005). Natural amenities include climatic, geographic (abiotic), and ecological (biotic) communities and processes specific to a particular region. In amenity migration analyses, natural amenities studied have included local temperatures, topography, water, public lands, and forest cover. Built amenities are a set of rural infrastructures and technologies providing access and services desired by migrants and include road systems, high-speed internet services, airports, and utilities. Social amenities include

\footnotetext{
${ }^{2}$ For a comprehensive review of early amenity migration research see Dearien et al. 2005. For a comprehensive review of amenity migration in the Pacific Northwest see Garber-Yonts (2004).
}

various differences in regional laws, crime rates, and presence of particular industries and employment and can be largely represented by community demographics. Cultural amenities are represented by organizations, arts, and communities that may attract migrants such as political, artisan, religious, ethnic, or other groups.

Protected public lands such as National Parks and National Monuments have generally been viewed as natural amenities, though built amenities such as recreational services (e.g., ski resorts) can influence the draw of regional natural amenities. However, designated federal public lands such as Wilderness or National Parks are natural amenities that have particular rules and regulations as defined by Congress, making protected public lands a special set of natural amenities. We term federal protected public lands ${ }^{3}$ as "designated natural amenities" and illustrate how these amenities are attractive for both their landscapes and their specific set of recreational opportunities and conservation legacies. For example, high-elevation mountain peaks have inherent natural features that attract many visitors or migrants regardless of the mountain's location. But protection levels from various designations can render a mountaintop accessible by only human power, or vice versa, the lack of protection can make the mountaintop accessible by a car. Beyond the mountain's physical features, being a designated natural amenity, or non-designated, offers various levels of commercialism, recreational opportunities, and access which have large ramifications for a region's general attractiveness. Played out across landscapes, we hypothesize that the "designation" level of protection has an influence on migration patterns to the rural West.

\section{Public Lands and Amenity Migration}

Regardless of metropolitan status or region, counties with federal lands across the U.S. have had higher mean population growth than counties without federal lands from 1970 to 2000 (Frentz et al. 2004). This population growth typically resulted in improved economic growth indicators, especially in the West. For example, Shumway and Otterstrom (2001) showed that rural New West counties, or those based more heavily on service industries and a high level of natural amenities, in the Mountain West received much greater in-migration and subsequent income as compared to rural counties based on resource extraction. In effect, amenity counties transitioned from being areas of production to being areas of consumption, diminishing the

\footnotetext{
${ }^{3}$ There are a number of federal protected area types in the U.S. In this study we focus on the most protective designation types only including National Parks, National Monuments, Wilderness Areas, Wilderness Study Areas, Roadless Areas, and Wild and Scenic Rivers.
} 
importance of resource extraction and increasing the demands for open space, conservation, and housing (Shumway and Otterstrom 2001).

Rudzitis (1996) illustrated that Western counties with Wilderness averaged greater population growth than counties without Wilderness. Duffy-Deno (1998) examined the role of Wilderness lands (including WSAs) in employment and population growth in the Intermountain West from 1980 to 1990 . He found that Wilderness had no effect on employment or population growth, indicating that Wilderness was not a major factor in early phases of amenity migration. ${ }^{4}$ Holmes and Hecox (2004) showed that rural Western counties with Wilderness Areas typically showed greater population growth than rural counties without Wilderness from 1970 to 2000. They also showed that counties with Wilderness had far more employment growth in both low-wage and high-wage service industries, which illustrates that most market indicators are enhanced when population growth is greater.

Most researchers have aggregated protected lands into a conglomerate amenity type. Lorah (2000) showed that Wilderness counties were associated with greater population and economic growth, but that the presence of multiple protected federal lands, including Wilderness, National Parks, National Monuments, and WSAs, was associated with even higher rates of employment, per capita income, total income, and population growth. Subsequent research from Lorah and Southwick (2003) found that populations of nonmetropolitan protected lands counties in the West grew 11.7 times faster than nonmetropolitan counties without protected lands, while the 50 nonmetropolitan counties with the most protected land grew 16.8 times faster from 1970 to 2000. For this study, "protected lands" included Wilderness, National Monuments, National Parks, and Roadless Areas. Dearien et al. (2005) examined migration and amenities in the interior Northwest and found that high amenity lands were a significant attractant for migrants. However, they found that the overall amount of federal lands was not significant, but that a subset of Wilderness, national forests, National Parks, and wildlife refuges were a positive attractant. Others have shown, via hedonic pricing methods, that protected public lands are amenities that people are willing to pay for and thus serve as an attractant to migrants. Hand et al. (2008) showed that proximity to Wilderness and to USFS lands resulted in higher housing prices as did Izón et al. (2016). Roadless Areas have also been shown to be considered an attracting amenity, as homes near New

\footnotetext{
${ }^{4}$ It should be noted that Duffy-Deno (1998) only included USFS and BLM Wilderness Areas, excluding Wilderness from NPS and USF\&W lands, and aggregated Wilderness Study Areas (WSAs) with designated Wilderness Areas. In addition, the Wilderness variable was a percentage of just a county's total federal lands, not a percentage of a county's total land area.
}

Mexico Roadless Areas are of higher value than equivalent houses not near Roadless Areas (Izón et al. 2010).

The existing research indicates that there are substantial differences in the types of public lands and their role in attracting amenity migrants. To wit, more protected public lands that have a greater focus on outdoor recreation and tourism, as opposed to resource extraction and grazing, are important public lands for migration. But the question remains-which types of protected lands are most influential for amenity migration?

\section{Methods}

Based on the existing body of research on amenity migration to rural areas, we know that certain types of variables hold considerable influence on where migrants relocate. Primary independent influencing variables include climate, topography, water availability, public lands, access, infrastructure, crime rates, and other social, economic, and cultural characteristics. Most of the research to date has looked at amenity migration trends for the entire country. But given that amenity migration is much more pronounced in the American West, and that the West contains the majority of public lands, there is a need to isolate Western states and types of public lands (see study area in Fig. 1).

\section{Model Specification}

Typical econometric investigations of amenity migration include simultaneous equations examining both net migration and employment growth, or the employment-migration model (e.g., Eichman et al. 2010). However, in this study, we are interested in understanding why some rural Western counties have been more successful than others in attracting amenity migrants. To estimate the influence of amenity supply, we constructed an econometric model that attempts to explain the most important attributes for attracting rural amenity migrants rather than examining economic outcomes of migration. Our dependent variable (Y) is the rate of in-migration, or out-migration, over a 30-year time period for every rural Western county (specifically, the average net migration rate of three successive decades). The source of our county migration rates come from the U.S. Census Bureau and Winkler et al. (2013). Focusing strictly on net migration allows for a more robust model concerning the supply of natural amenities.

To investigate the factors that may explain the differences in 30-year migration rates among Western counties, we account for general amenity migrant attractors such as climatic, geographic, demographic, and public land attributes. Amenity migrants tend to be attracted to sunny places with mild winters. However, in the American West, due to 


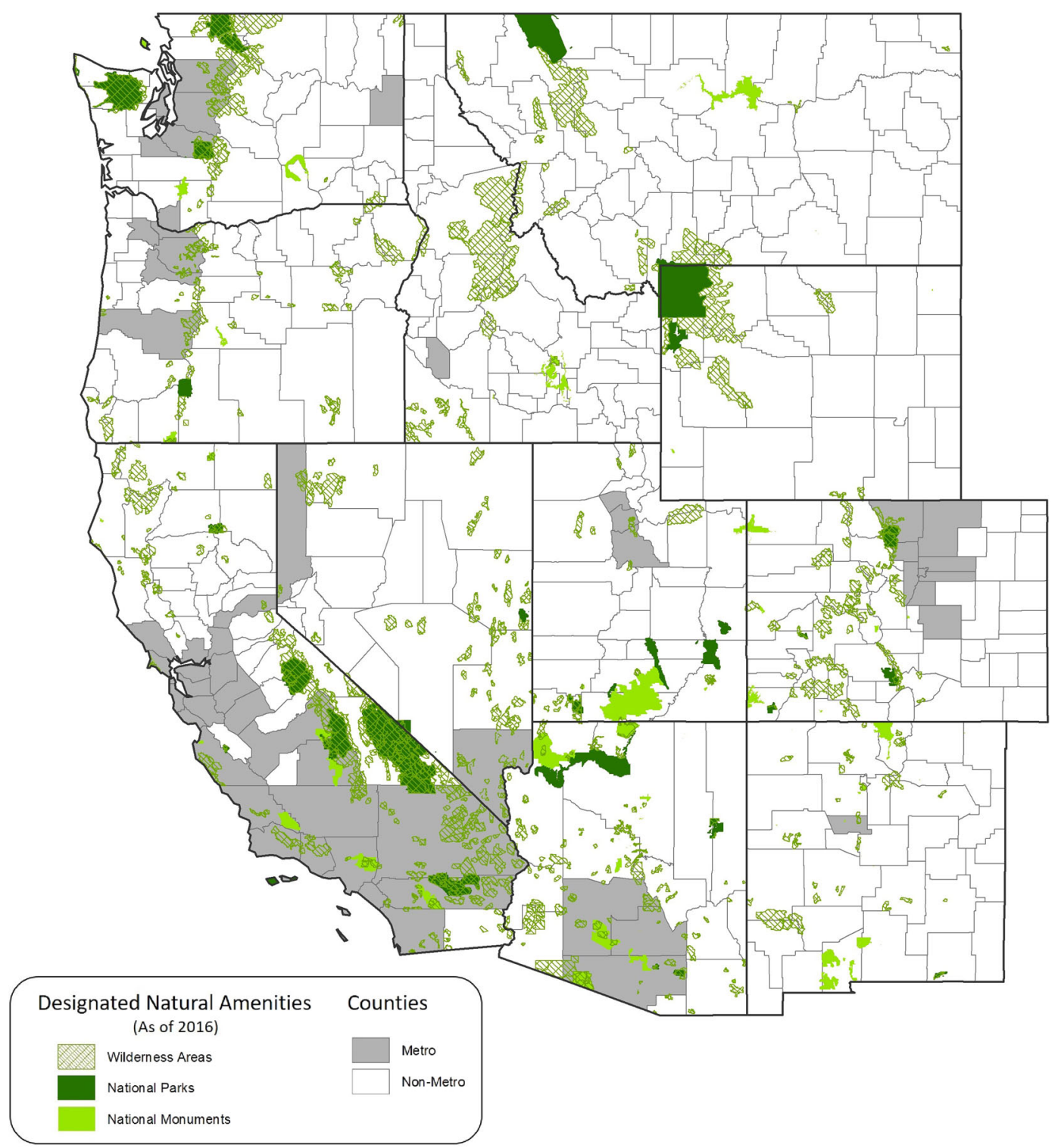

Fig. 1 Study area of protected areas and the American West

vast areas of arid, desert-like landscapes, there is also a premium on water availability and cool summers.

We hypothesize that the rate of amenity migration (AM) for each rural Western county is a function of the level of natural amenities $(\mathrm{N})$, built amenities (B), social amenities (S), and designated natural amenities (DN) such as the categories and aggregate level of ecosystem protection. Formally,

$\mathrm{AM}_{\mathrm{j}}=\mathrm{F}(\mathrm{N}, \mathrm{B}, \mathrm{S}, \mathrm{DN})$,

in this equation, $\mathrm{AM}_{\mathrm{j}}$ is the average 30-year net migration rate documented in the $j_{\text {th }}$ county included in the analysis. This amenity migration rate is composed of the following attributes. $\mathrm{N}$ is a vector of variables indicating the natural amenity characteristics for each county. B is a vector of variables representing built amenity characteristics for each county. S is a vector of each county's social amenity characteristics such as population, wages, and the type of economic industries most prevalent. DN represents a vector of designated natural amenities in each county, or the amount and presence of various protected public lands types.

In neoclassical economic terms, the motivation for migrants to relocate is to improve their overall utility level. Traditionally, this has meant moving to a place that increases personal income through higher wages, business profits, or service production. Recent evidence indicates that bundles of amenities are often more important factors than wages or rents when considering relocation, leading to cohorts of people that make decisions about where to live 
primarily based on the suite of natural amenities available. Thus, our amenity migration model is a reduced form of a representative decision maker model. This theoretical model leads to suggestive results but can be prone to aggregation biases as some people are still moving just for employment or other reasons not fully captured by our model. It is the specification of DN in Eq. (1), along with the strict focus on rural Western counties, that distinguishes this amenity migration analysis from previous studies that have examined the economic supply and influence of amenities. In the following section, we provide greater detail on the classification of independent variables for natural $(\mathrm{N})$, built $(\mathrm{B})$, social (S), and designated natural (DN) amenities.

\section{Data Selection}

The data used in this study were compiled from several sources. Data on the dependent variable "average county net migration rate" pertaining to 356 nonmetro rural counties with population less than 250,000 in 2010 were obtained from U.S. Census Bureau and Winkler et al. (2013). Specifically, the dependent variable is the average net migration rate for three decades from 1980 to 2010 (1980s, 1990s, and 2000s) for all counties. ${ }^{5}$ The dependent variable is a continuous variable that may be negative or positive and is not bounded. We use net migration rates as illustrated in Fig. 2, as opposed to the actual number of new or lost migrants, to compare migration changes among rural counties of various population sizes. We focus on the three decades from 1980 to 2010 as this period broadly encompasses the amenity migration effect in the rural West. We restrict our analysis to the rural West, as the majority of public lands are in the West and there is greater homogeneity among rural counties in terms of economics, climate, and geographies when compared with the eastern U.S. While there are a number of definitions of "rural", we used a county population threshold of less than 250,000 people to account for the large geographic area (acres) of many of the counties in the West (i.e., population density of Western counties is typically much lower than counties in the eastern U.S).

The natural amenity category includes climatic and geographic attributes of each county, along with federal land management distribution across agencies. We used McGranahan's (1999) county-level measures for temperature,

\footnotetext{
5 Winkler et al. 2013 estimate net migration at the county-level by decade. For each decade, an "expected population" was modeled based on county age cohorts, births, and deaths for the starting population, as actual births and deaths are not easily tracked. New migrants (or lost migrants) are calculated as the difference between the final population at the end of the decade and the modeled "expected population". Net migration rates are calculated as the ratio of new migrants to expected populations at the end of each decade. Thus, our 30-year average equals \{(change_1990-1980)+(change_2000-1990) $+($ change_20102000)\}/3.
}

sunlight, humidity, topography, and water area. County land cover class acres (e.g., shrub, forest, mountains) were included as a natural amenity as migrants may prefer, for example, forests in the arid West (Hjerpe et al. 2016). Land cover class acres from the National Agriculture Imagery Program (NAIP) from 2011 were tabulated for 12 separate land cover types for each county in ArcGIS and county percentages and land cover dominance (as dummy variables) were estimated for the top five land covers. Federal land management by agency was allocated across counties to include the percent of every rural county managed by the USFS, the NPS, the BLM, and the USFWS. Federal land management types were collected from the PAD-US Version 1.4 data layers from 2016 (USGS 2016). Land cover classes, amount of agency-managed lands, geographic attributes, and climate variables were all expected to be relatively static throughout the 30 -year migration period.

We include some human built amenities in the model specification such as overall infrastructure, proximity to urban areas, and community accessibility given the influential role of these variables in attracting Western amenity migrants (Rasker et al. 2009). As articulated by Power (2005), the existence of differential access costs to natural amenities has an overarching role in the economic supply of natural amenities. For example, high natural amenity areas that are extremely isolated (e.g., Alaska) have too high of an access cost to pursue amenity development. To account for built infrastructure, regional access, and connectedness of rural counties, we include county typologies from Headwaters Economics (2015) that breaks rural counties into three types: metro, connected, and isolated. While we did not include any metropolitan counties, the typology of rural counties means that "metro" is located near a larger metropolitan statistical area (MSA). "Connected" describes rural counties not close to metropolitan areas but that have an airport. "Isolated" rural counties have very limited access. Other built amenities that we investigated include the presence of a ski resort, as skiing is a major Western attraction. We did not include other forms of built recreational amenities such as trails or camping facilities as we presume these amenities are covered by our designated natural amenities of protected areas and various types of public lands.

There are numerous social characteristics of a region that may be considered as amenities or disamenities to migrants. Many of these social amenities are represented as regional demographic and economic indicators such as wages and regional cost of living. For example, migrants may be concerned with typical annual pay in a region, leading us to include average annual pay for all covered jobs from 2001 to 2010 from the Bureau of Labor Statistics. Cost of living is a concern for everybody-we include a cost of living proxy based on housing prices, specifically the percent of houses valued over $\$ 200,000$ in the year 2000 from the US 


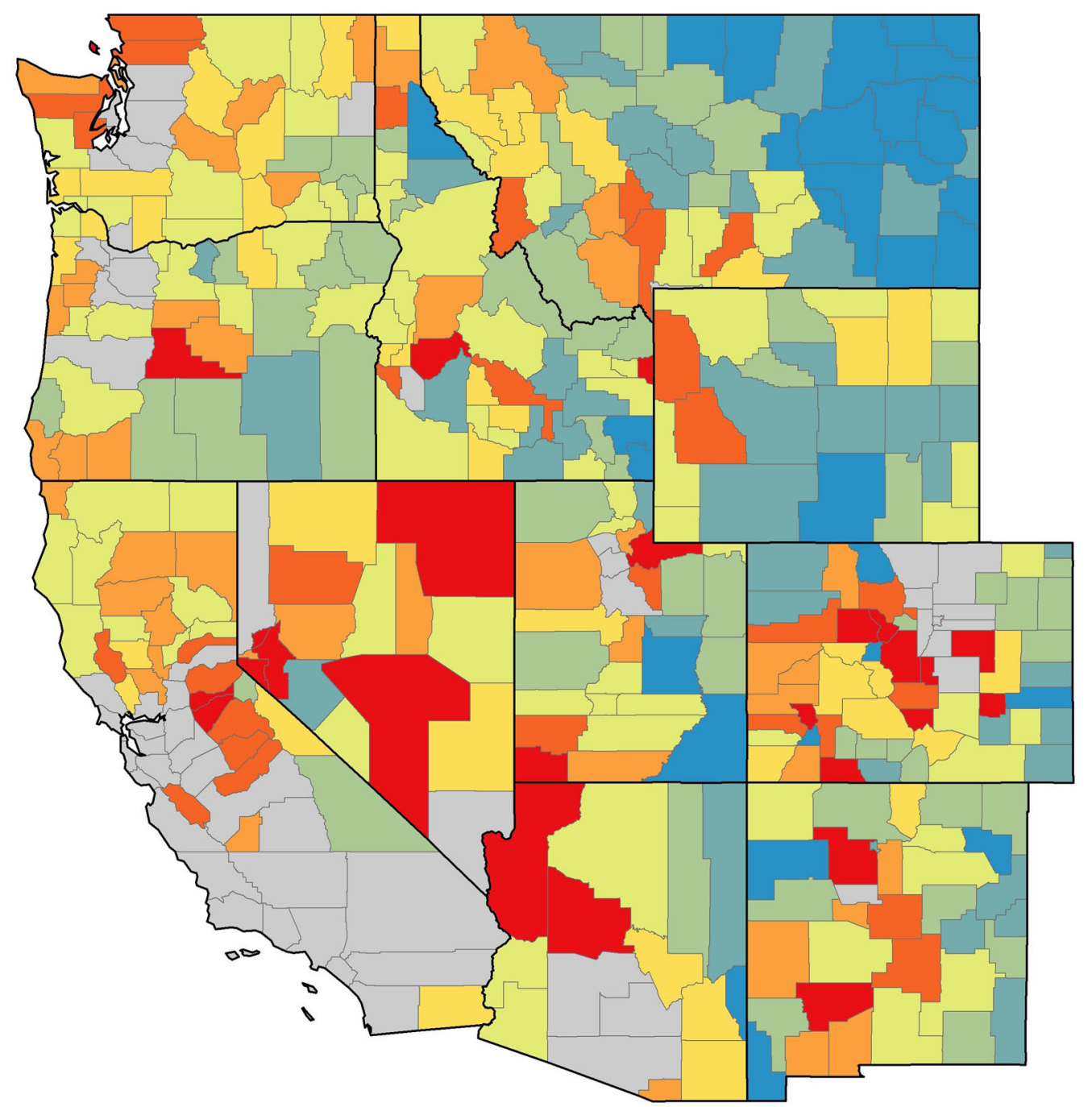

\begin{tabular}{|l|l|}
\hline Net Migration Rates $\mathbf{1 9 8 0 - 2 0 1 0}$ & 0\% to $5 \%$ \\
\hline Metro Counties & $5 \%$ to $10 \%$ \\
\hline$<-10 \%$ & $10 \%$ to $15 \%$ \\
$-10 \%$ to $-5 \%$ & $15 \%$ to $25 \%$ \\
\hline$-5 \%$ to $0 \%$ & $>25 \%$ \\
\hline
\end{tabular}

Fig. 2 Average county net migration rates for three decades from 1980 to 2010 (dependent variable)

Census Bureau. Average state income tax levels and effective state tax levels (including income, property, and sales taxes) were also tabulated and investigated. Migrants may be influenced by the type of jobs available, leading us to include four regional economic industry measures: prevalence of high-wage service industries, oil and gas industries, farming dependency, and retirement destination rankings. These economic measures were taken from Headwaters Economics (2014) for 2000-2012. Industry predominance for each county is from the latter portions of the migration period studied. We presume that counties had similar industrial tendencies throughout the 30 -year migration period but acknowledge that industry ratios underwent changes throughout our time horizon. ${ }^{6}$ Migrants may also want to be among certain population size demographics.

\footnotetext{
${ }^{6}$ With the exception of sporadic oil and gas booms, we expect that most county industry ratios changed slowly towards increased levels of services throughout the study time horizon given the overall Western rural economic restructuring.
} 
Demographic variables used in our analysis included county population from 2000 to 2010, taken from the Bureau of Economic Analysis (BEA), and individual states which represent separate institutions and regional economies. Finally, we considered but ultimately did not include any cultural amenities in our analysis as we considered most cultural amenities to be heterogenous, local, and too dispersed to have a significant influence on rural Western amenity migration. Cultural amenities have been rarely included in previous amenity migration research.

Our final category of variables used in the regression analysis is "designated" natural amenities; these include administratively and congressionally designated federal lands and groups of protected areas. Protected areas in the analysis included Wilderness Areas, National Parks, National Monuments, Roadless Areas, Wild and Scenic Rivers, and WSAs. For all designated natural amenities, the Protected Areas Database (PAD-US) Version 1.4 data layers from 2016 were used (USGS 2016). In addition to independent variables measuring the percent of county land represented by protected areas, dummy variables were generated to signify whether protected areas were present or not. As some protected areas have been added throughout the 30 years of our study period, we assume that landscape characteristics of protected areas, prior to their designation, were similar in attractiveness to existing protected areas. Table 1 presents the full list of variables investigated.

\section{Regression Diagnostics}

To select the appropriate regression model, we relied on insights gained from the literature on amenity migration as well as application of statistical criteria (i.e., smaller mean square error, higher R-square, appropriate coefficient signs). However, we could not use Box-Cox transformations because of zero values taken by dummies variables included in the specification as the log of a zero or negative number is undefined. After a thorough, a priori model specification of variables most likely to influence amenity migration, we used stepwise regression to select the minimal set of relevant explanatory variables. The best model fit had the dependent variable expressed as a linear function of all the explanatory variables measured as levels or dummies.

To determine that assumptions underlying OLS estimation were met, several diagnostics tests were conducted including assessments of collinearity, heteroskedasticity, and outliers. Empirical regression studies report that linear regression models are often plagued by multicollinearity because of the inclusion of seemingly similar but otherwise relevant and distinct explanatory variables in the reduced specification form. This was the case for our study. To assess the degree of collinearity, variance inflation factors (VIFs) and condition numbers were computed. After dropping similar and highly collinear variables, the final model had a mean value of $\mathrm{VIF}^{7}$ of less than 10 (O'Brien 2007) and condition number of 31 (Belsley 1991), suggesting only mild collinearity. To detect heteroskedasticity, the Breusch-Pagan/Cook-Weisberg test was used and indicated that the null hypothesis of homoskedasticity (constant variance) should be rejected at the conventional levels of significance $\left(\chi^{2}(1)=72.42 ; p>\chi^{2}=0.000\right)$. Thus, we re-estimated the model to obtain robust standard errors. Finally, a calculated Cook distance measure of less than 1 suggested that the data did not have outliers.

Given the spatial nature of our data, we tested for the coincidence of value similarity with locational similarity, or the level of spatial autocorrelation (Anselin and Bera 1998). Spatial data can violate the assumption of observation independence necessary for standard regression analysis (LeSage 2014). We followed a specific-to-general approach (Elhorst 2014), beginning with nonspatial linear regressions and then investigating spatial regressions. A Moran's I test and robust Lagrange Multipliers indicated that spatial autocorrelation may be present in the data. However, results from fully specified spatial lag, error, and mixed models yielded virtually no noticeable differences on coefficient estimates and $t$-statistics and results were insensitive to various distance bands. In addition, overall information criteria (e.g., AIC and BIC) indicated that the nonspatial regressions were of better fit. Ultimately, spatial autocorrelation was not deemed to be an issue for our rural Western county data, perhaps due to the relatively large distances between counties as compared to distances between neighborhoods and houses.

Similar to our spatial investigation, we also fitted and tested multilevel models. Multilevel models, or mixed models, can be appropriate for nested data where there is a hierarchical order or grouping of potential explanatory variables. Without recognizing clustered data, standard errors for regression coefficients will be underestimated and significance of variables (especially the clustered group) may be overstated (Gelman and Hill 2006). Amenity migration in rural Western counties occurs within a clustering of 11 individual states, offering a logical grouping for multilevel analysis. To investigate state-level groupings, we estimated a number of multilevel models with random effects but found little impact on variable coefficients and significance. Using model estimators such as AIC and BIC, we found that standard OLS regressions incorporating states as dummy variables were a better fit. Allowing for state

\footnotetext{
${ }^{7}$ A VIF of 10 indicates that (all other things being equal) the variance of the $i$ th regression coefficient is 10 times greater than it would have been if the $i$ th independent variable had been linearly independent of the other independent variable in the analysis. Thus, it tells us how much the variance has been inflated by this lack of independence (O’Brien 2007).
} 
Table 1 Description of variables used in the regression analysis

\begin{tabular}{|c|c|c|c|}
\hline Variable name & Definition & Data source & Expected sign \\
\hline $\begin{array}{l}\text { Dependent variable: average net } \\
\text { migration rate }\end{array}$ & $\begin{array}{l}\text { 3-decade average net migration rate for the county } \\
(1980-2010)\end{array}$ & $\begin{array}{l}\text { U.S. Census and Winkler et al. } \\
\text { (2013) }\end{array}$ & \\
\hline \multicolumn{4}{|l|}{ Explanatory variables } \\
\hline \multicolumn{4}{|l|}{ Natural amenities $(\mathrm{N})$} \\
\hline January temperature & County average January temperature $1941-1970$ & McGranahan (1999) & + \\
\hline January sunlight & County number of sunny January days 1941-1970 & McGranahan (1999) & + \\
\hline July temperature & County average July temperature $1941-1970$ & McGranahan (1999) & - \\
\hline July humidity & County average July humidity \% 1941-1970 & McGranahan (1999) & - \\
\hline Topography & County topographic variation ranking & McGranahan (1999) & + \\
\hline Water area & Water area as a $\%$ of total county area & McGranahan (1999) & + \\
\hline \multicolumn{4}{|l|}{ Land cover } \\
\hline Forest and woodland & $\begin{array}{l}\% \text { county acres and If land cover is dominant, } \\
\text { dummy }=1\end{array}$ & NAIP land cover (2011) & + \\
\hline Shrub and herb veg & $\begin{array}{l}\% \text { county acres and If land cover is dominant, } \\
\text { dummy }=1\end{array}$ & NAIP land cover (2011) & $?$ \\
\hline Desert and semidesert & $\begin{array}{l}\% \text { county acres and If land cover is dominant, } \\
\text { dummy }=1\end{array}$ & NAIP land cover (2011) & $?$ \\
\hline Polar and high montane & $\begin{array}{l}\% \text { county acres and If land cover is dominant, } \\
\text { dummy }=1\end{array}$ & NAIP land cover (2011) & $?$ \\
\hline Agricultural—developed & $\begin{array}{l}\% \text { county acres and If land cover is dominant, } \\
\text { dummy }=1\end{array}$ & NAIP land cover (2011) & $?$ \\
\hline \multicolumn{4}{|l|}{ Land management } \\
\hline USFS acres & $\%$ of county acres managed by USFS & PAD US version 1.4 (2016) & + \\
\hline NPS acres & $\%$ of county acres managed by NPS & PAD US version 1.4 (2016) & + \\
\hline BLM acres & $\%$ of county acres managed by BLM & PAD US version 1.4 (2016) & $?$ \\
\hline USFWS acres & $\%$ of county acres managed by USFWS & PAD US version 1.4 (2016) & $?$ \\
\hline \multicolumn{4}{|l|}{ Built amenities (B) } \\
\hline \multicolumn{4}{|l|}{ Infrastructure/Access } \\
\hline Metro & If county is located near a larger MSA, dummy $=1$ & Headwaters Economics (2015) & + \\
\hline Connected & If county is rural but has airport, dummy $=1$ & Headwaters Economics (2015) & $?$ \\
\hline Isolated & If county is rural and has limited access, dummy $=1$ & Headwaters Economics (2015) & $?$ \\
\hline Ski resorts & If county has a ski resort, dummy $=1$ & Wikipedia (2018) & $?$ \\
\hline \multicolumn{4}{|l|}{ Social amenities (S) } \\
\hline Population & County population & BEA 2000, (2010) & $?$ \\
\hline Wages & $\begin{array}{l}\text { County average annual pay (thousand\$) for } \\
2001-2010\end{array}$ & BLS (2001-2010) & + \\
\hline Cost of living & County $\%$ of housing $>\$ 200,000$ in 2000 & US Census and Winkler (2010) & - \\
\hline State tax rate & Average state income tax and effective state tax rate & Wikipedia (201) & - \\
\hline Service dependency & $\begin{array}{l}\text { Ranking of high-wage service jobs dependency } \\
(0-100)\end{array}$ & $\begin{array}{l}\text { Headwaters Economics } \\
(2000-2012)\end{array}$ & $?$ \\
\hline Farm dependency & Ranking of farm dependency $(0-100)$ & $\begin{array}{l}\text { Headwaters Economics } \\
(2000-2012)\end{array}$ & $?$ \\
\hline Oil and gas dependency & Ranking of oil and gas dependency $(0-100)$ & $\begin{array}{l}\text { Headwaters Economics } \\
(2000-2012)\end{array}$ & $?$ \\
\hline Retirement destination & Ranking of retirement destination score $(0-100)$ & $\begin{array}{l}\text { Headwaters Economics } \\
(2000-2012)\end{array}$ & + \\
\hline State (11 Western states) & Dummy variable for each state & & \\
\hline \multicolumn{4}{|l|}{ Designated natural amenities (DN) } \\
\hline \multicolumn{4}{|l|}{ Protected areas } \\
\hline Wilderness Areas & $\%$ of county acres and presence dummy $=1$ & PAD US version 1.4 (2016) & + \\
\hline
\end{tabular}


Table 1 (continued)

\begin{tabular}{llll}
\hline Variable name & Definition & Data source & Expected sign \\
\hline National Parks & $\%$ of county acres and presence dummy $=1$ & PAD US version $1.4(2016)$ & + \\
Roadless Areas & $\%$ of county acres and presence dummy $=1$ & PAD US version $1.4(2016)$ & $?$ \\
National Monuments & $\%$ of county acres and presence dummy $=1$ & PAD US version $1.4(2016)$ & $?$ \\
Wild and Scenic Rivers & $\%$ of county acres and presence dummy $=1$ & PAD US version $1.4(2016)$ & $?$ \\
Wilderness Study Areas & $\%$ of county acres and presence dummy $=1$ & PAD US version $1.4(2016)$ & $?$ \\
\hline
\end{tabular}

group effects with dummy variables also provided more information on individual states and afforded more traditional coefficient interpretation.

\section{Results}

The final estimation had an R-squared of 0.484 and included 14 significant explanatory variables. Natural amenity variables for rural Western counties most highly associated with net migration rates included average January temperatures, average July humidity levels, and open water. As average January temperature increases, so does inmigration. As average July humidity increases, inmigration decreases. Built infrastructure and access to rural counties was highly associated with levels of migration, with connected counties and those adjacent to metro areas attracting higher rates of migrants. Rural counties closer to big cities have grown much faster than more rural and isolated counties. Table 2 presents the descriptive statistics for the final variables remaining in the model.

Statistically significant social amenities included certain states and retirement destinations. The high presence of farming in a county was negatively associated with migration rates, as was oil and gas dependency. A county's cost of living was positively associated with migration which is a result of increased housing prices resulting from a greater influx of amenity migrants. The states of Nevada and Colorado were positively associated with migration rates. It is worth noting that Nevada does not have a state income tax, even though effective and state income tax variables were ultimately not quite significant influencers of amenity migration in this study. Montana rural counties, on the other hand, were clearly negatively associated with migration, but were collinear with January temperatures and climatic variables that better explained migration rates.

Finally, two types of protected areas, Wilderness and National Monuments were strongly associated with a county's amenity migration and the amount of county land managed by the US Fish and Wildlife Service was inversely associated with migration. USFWS has a much lower spatial distribution of agency-managed lands as compared with the other major federal land management agencies, allowing
Table 2 Descriptive statistics of variables used in the final regression analysis $(n=356)$

\begin{tabular}{lrrrr}
\hline Variable & Mean & Std. Dev. & \multicolumn{1}{l}{ Min } & Max \\
\hline $\begin{array}{l}\text { Average net migration rate } \\
\text { (1980-2010) }\end{array}$ & 4.728 & 12.351 & -15.63 & 64.33 \\
Natural amenities (N) & & & & \\
January temperature & 27.748 & 9.231 & 5.70 & 55.40 \\
July humidity (\%) & 29.441 & 10.852 & 14.00 & 74.00 \\
Water area (\% of county) & 2.058 & 6.127 & 0.00 & 71.83 \\
USFWS acres (\% of county) & 0.615 & 2.142 & 0.00 & 27.95 \\
$\begin{array}{l}\text { Built amenities (B) } \\
\text { Metro (dummy) }\end{array}$ & 0.219 & 0.414 & 0.00 & 1.00 \\
Connected (dummy) & 0.216 & 0.412 & 0.00 & 1.00 \\
$\begin{array}{l}\text { Social amenities (S) } \\
\text { Cost of living }\end{array}$ & 15.205 & 14.700 & 0.00 & 82.62 \\
(\% houses > \$200 K in 2000) & & & & \\
$\begin{array}{l}\text { Farm dependency (ranking } \\
\text { from 0 to 100) }\end{array}$ & 27.753 & 28.175 & 0.00 & 100.00 \\
$\begin{array}{l}\text { Oil and gas dependency } \\
\text { (ranking from 0 to 100) }\end{array}$ & 16.517 & 25.102 & 0.00 & 100.00 \\
$\begin{array}{l}\text { Retirement destination } \\
\text { (ranking from 0 to 100) }\end{array}$ & 39.677 & 23.895 & 0.00 & 100.00 \\
$\begin{array}{l}\text { Colorado (dummy) } \\
\text { Nevada (dummy) }\end{array}$ & 0.152 & 0.359 & 0.00 & 1.00 \\
$\begin{array}{l}\text { Designated natural amenities (DN) } \\
\text { Wilderness Areas (dummy) }\end{array}$ & 0.576 & 0.495 & 0.00 & 1.00 \\
$\begin{array}{l}\text { National Monuments } \\
\text { (dummy) }\end{array}$ & 0.194 & 0.396 & 0.00 & 1.00 \\
\hline & & & & \\
\hline
\end{tabular}

for one very large refuge (the Charles M. Russell National Wildlife Refuge) in northeastern Montana to effectively drive the negative USFWS net migration rate coefficient. In this region, six contiguous counties had substantial outmigration over three decades, with average decadal net migration rates of -12 percent. Testing USFWS lands as a dummy variable (presence/no presence) resulted in an insignificant coefficient. Table 3 presents the final estimation results and implicit interpretation.

To provide a greater level of detail and to address the robustness of our 30-year model, we conducted decadal regressions for five time periods including the 1980s, 1990s, 2000s, 1980-2000, and 1990-2010 (see Table 4). We found 


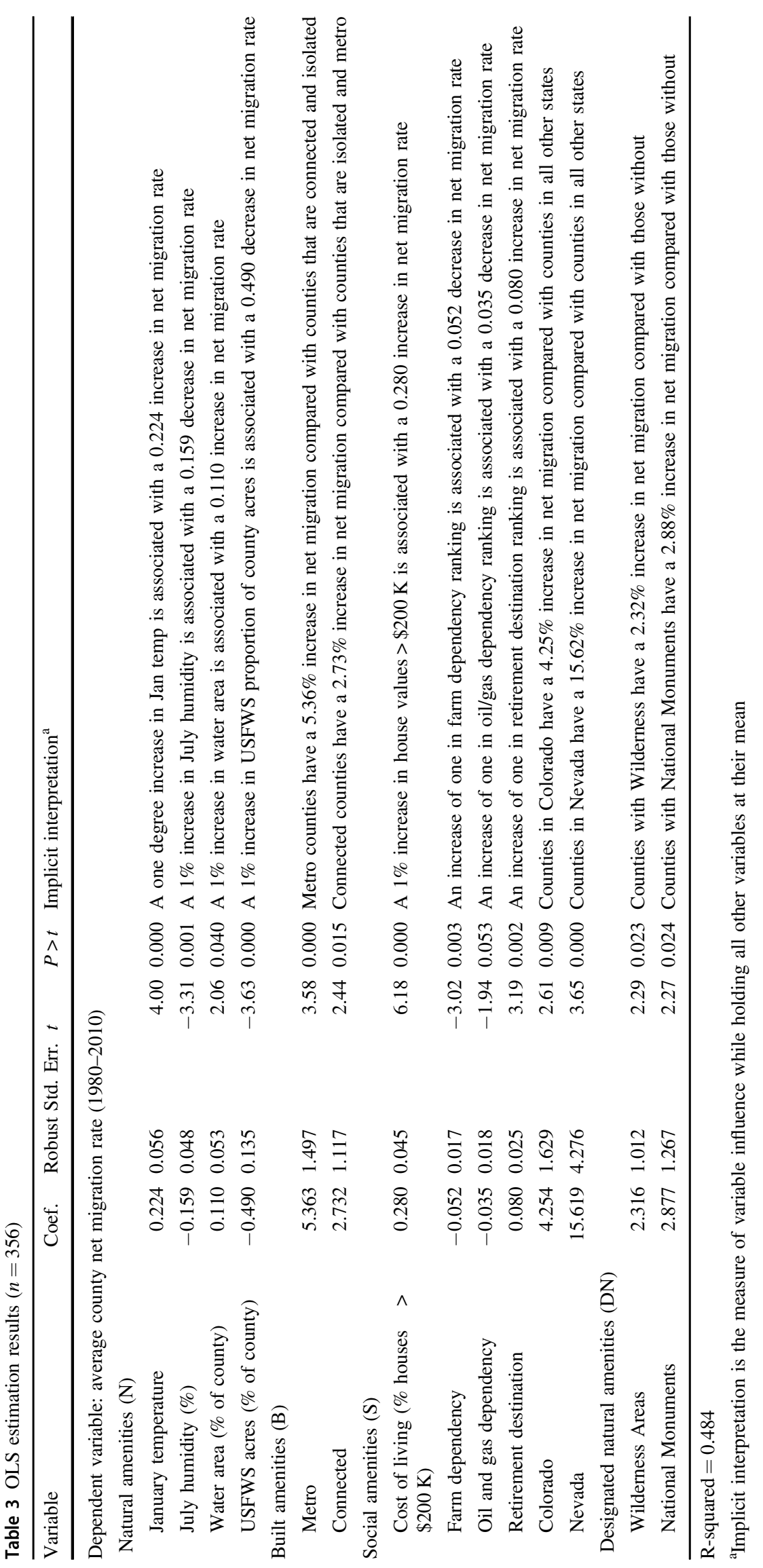


Table 4 Regression estimates for rural county migration in decadal intervals $(n=356)$

\begin{tabular}{|c|c|c|c|c|c|c|c|c|c|c|}
\hline \multirow{3}{*}{$\begin{array}{l}\text { Variable* } \\
\text { Dependent variable: county net migration rate } \\
\text { (R-squared) }\end{array}$} & \multirow{2}{*}{\multicolumn{2}{|c|}{$\frac{1980 \mathrm{~s}}{(0.5010)}$}} & \multirow{2}{*}{\multicolumn{2}{|c|}{$\frac{1990 \mathrm{~s}}{(0.4461)}$}} & \multirow{2}{*}{\multicolumn{2}{|c|}{$\frac{2000 \mathrm{~s}}{(0.3277)}$}} & \multirow{2}{*}{\multicolumn{2}{|c|}{$\frac{1980-2000}{(0.4997)}$}} & \multirow{2}{*}{\multicolumn{2}{|c|}{$\frac{1990-2010}{(0.4166)}$}} \\
\hline & & & & & & & & & & \\
\hline & Coeff. & $P$ value & Coeff. & $P$ value & Coeff. & $P$ value & Coeff. & $P$ value & Coeff. & $P$ value \\
\hline \multicolumn{11}{|l|}{ Natural amenities $(\mathrm{N})$} \\
\hline January temperature & 0.37 & 0.000 & 0.34 & 0.000 & - & - & 0.36 & 0.000 & 0.23 & 0.001 \\
\hline January sun & 0.03 & 0.087 & - & - & -0.02 & 0.002 & - & - & - & - \\
\hline July humidity (\%) & - & - & -0.29 & 0.000 & - & - & -0.17 & 0.002 & -0.19 & 0.000 \\
\hline Water area (\% of county) & 0.18 & 0.080 & - & - & - & - & - & - & - & - \\
\hline USFWS acres ( $\%$ of county) & -0.62 & 0.021 & -0.83 & 0.000 & - & - & -0.71 & 0.000 & - & - \\
\hline \multicolumn{11}{|l|}{ Built amenities (B) } \\
\hline Metro (dummy) & 7.68 & 0.000 & 5.94 & 0.009 & - & - & 5.94 & 0.002 & 4.46 & 0.004 \\
\hline Connected (dummy) & 3.27 & 0.042 & 3.40 & 0.057 & - & - & 2.79 & 0.041 & 2.98 & 0.019 \\
\hline \multicolumn{11}{|l|}{ Social amenities (S) } \\
\hline Cost of living ( $\%$ houses $>\$ 200 \mathrm{~K}$ ) & 0.29 & 0.000 & 0.48 & 0.000 & 0.07 & 0.039 & 0.39 & 0.000 & 0.30 & 0.000 \\
\hline High-wage service dependency & - & - & - & - & 0.10 & 0.000 & - & - & - & - \\
\hline Farm dependency & - & - & -0.07 & 0.018 & -0.07 & 0.000 & -0.04 & 0.033 & -0.07 & 0.000 \\
\hline Oil and gas dependency & -0.07 & 0.010 & -0.08 & 0.001 & - & - & -0.07 & 0.001 & - & - \\
\hline Retirement destination & - & - & 0.09 & 0.012 & 0.13 & 0.000 & 0.06 & 0.061 & 0.11 & 0.000 \\
\hline California (dummy) & 11.51 & 0.001 & -14.65 & 0.000 & - & - & - & - & -9.96 & 0.000 \\
\hline Colorado (dummy) & - & - & 11.51 & 0.000 & - & - & 6.61 & 0.002 & 4.86 & 0.003 \\
\hline Nevada (dummy) & 35.63 & 0.000 & - & - & 8.05 & 0.021 & 20.49 & 0.000 & - & - \\
\hline Utah (dummy) & - & - & - & - & 3.65 & 0.023 & - & - & - & - \\
\hline Wyoming (dummy) & - & - & - & - & 5.47 & 0.027 & - & - & - & - \\
\hline \multicolumn{11}{|l|}{ Designated natural amenities (DN) } \\
\hline Wilderness Areas (dummy) & 3.79 & 0.005 & 3.46 & 0.029 & - & - & 3.15 & 0.014 & 2.03 & 0.054 \\
\hline National Monuments (dummy) & 3.61 & 0.036 & - & - & 2.34 & 0.042 & 3.53 & 0.028 & - & - \\
\hline
\end{tabular}

*Only significant variables $(p<0.10)$ are listed for each decadal regression

that our amenity migration model appeared to capture much of the migration effect for the 1980s and 1990s. However, our amenity migration model began to unravel in the 2000s, going from an R-squared value of 0.50 in the 1980 s to 0.33 in the 2000s. Variables such as infrastructure and connectedness, warmer winters, and water area, were no longer as relevant to rural migration in the 2000s. States such as Wyoming and Utah became positively associated with rural migration rates in the 2000 s, primarily due to natural gas, coal-bed methane, oil, and coal production. Rising energy prices and resulting increased commodity extraction led to greater heterogeneity among rural county economic structures during the 2000s than during the two previous decades. In addition, the Great Recession reduced mobility and excess income, dampening amenity migration despite longterm trends of decreasing federal interest rates and available credit. Finally, both the significance and coefficient for the cost of living proxy began to drop in the 2000s. While still positively associated with migration rates, the decreasing association trend for cost of living indicates a shift to the next best places that are slightly more affordable and a saturation of amenity migration in the most expensive locations. For example, rural migration in Colorado dropped precipitously in the 2000s from an average of 23 percent in the 1990s to an average of two percent in the 2000s.

The decadal analyses illustrate that we have captured the rise and fall of Western amenity migration, justifying our 30year time period. The decadal analyses also strengthen the robustness of the final model estimate from 1980 to 2010 by providing contextual nuance for individual time periods and greater ability for replication. To address issues previously identified in stepwise regressions, all potential explanatory variables were scrutinized with simple (and simpler) regressions with the dependent variable. In addition, descriptive statistics of potential explanatory variables were analyzed so as to compare our a priori model specification to our final OLS estimates, with both models being fairly similar.

\section{Protected Areas and Amenity Migration}

In our regression analysis, we found that Wilderness and National Monuments were the designated natural amenities 
Fig. 3 County average net migration rate with/without protected areas (1980-2010)

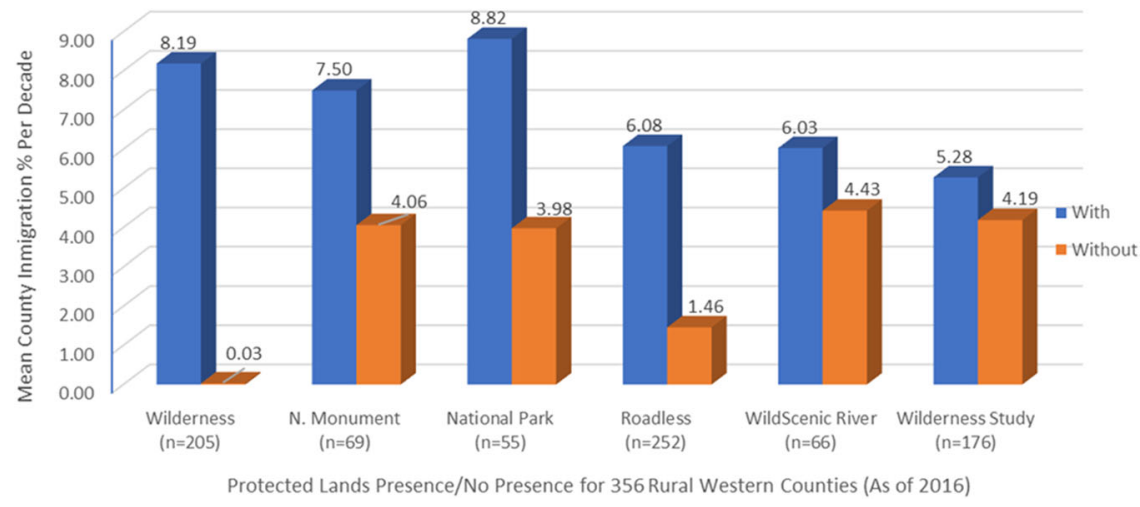

Discussion

most influential for Western amenity migration and on par with traditional migration factors of climate and regional access. However, a closer look at the descriptive migration statistics for all protected lands shows a clear picture of their importance in the Western amenity migration phenomenon. Figure 3 shows our calculated mean in-migration rates for rural Western counties with and without six types of protected lands taken. County presence for all six categories of protected lands had higher rates of county net migration compared to rural counties without protected lands. Counties with Wilderness Areas led the way with the greatest differential in net migration rates from 1980 to 2010. Rural Western counties with Wilderness averaged over eight percent in-migration, while rural counties without Wilderness had zero growth on average. The presence of Roadless Areas is also a powerful influence on amenity migration. But, due to collinearity with Wilderness presence (184 counties have both Wilderness and Roadless Areas), Roadless Area presence was eliminated from our regression model.

Counties with multiple types of protected areas fared even better in terms of net migration rates. For example, 15 counties contained a National Park, a National Monument, and a Wilderness Area. These counties averaged almost 11 percent in-migration from 1980 to 2010. Counties with protected areas in the rural West are associated with higher in-migration rates and, based on other research, have greater economic performance measures particularly associated with per capita income, per capita income growth, and per capita investment income (Rasker et al. 2013). While the presence, or lack thereof, of protected areas has measurable effects on rural migration rates in the West, the size of protected areas also matters. For example, the percent of counties designated as National Monuments had interaction effects with the presence indicator (i.e., dummy variable) but was significantly associated with greater migration rates when analyzed without the presence indicator. This indicates that efforts to reduce the size of National Monuments, as recently done by the current Administration, will likely hinder a region's ability to capitalize on amenity migration development.
Like Dearien et al. (2005), we found that the total of amount of federal lands in a county was not an explanatory factor for amenity migration in the rural West. Instead, it was two types of protected public lands that were most highly associated with greater in-migration, Wilderness and National Monuments. Most natural amenities such as climate and geography are fairly static across a few decades. But built, social, and designated natural amenities can all fluctuate over 30 years. Given the data limitations for annual reporting and the need to compare a dynamic dependent variable to static independent variables, we chose to use data from the latter parts and after the study period. While we did not investigate the change in net migration rates before and after designations, we do see this as a future research need as Jakus and Akhundjanov (2019) have done with National Monuments and per capita income. Likewise, greater spatial resolution, such as examining migration at the census area level, as done by Winkler et al. (2007), would be beneficial and may highlight more nuanced differences among protected area types.

Our analysis shows that some designated natural amenities are more influential than others. In particular, the presence of Wilderness and National Monuments in a county is associated with greater in-migration when accounting for other amenity migration drivers. Protected lands, including Wilderness and National Monuments, have been shown to have the highest elevations (and likely some of the most varied topography) and the lowest soil productivity compared with all other lands (Aycrigg et al. 2013). We did not find topographic variation to be a significant influence on migration in the rural West, but McGranahan (1999) found that topography was a significant supply variable for amenity migration across the nation. Traditionally, the economic geography of Wilderness led to a comparative economic disadvantage for capitalizing on commodity production and manufacturing (Hjerpe et al. 2017). But when examining Western amenity migration, Wilderness and National Monuments have gone from being the most remote and least developed lands to becoming the most influential attractors among public lands. 
In discussing the tendency for natural amenities to be non-producible, Marcouiller and Clendenning (2005) acknowledge that there are exceptions and that the creation of public parks and open space are basically a means to produce amenities, or at the least, can be used to increase the regional capture of amenity values. There is a market premium for counties with designated protected lands. While not entirely producible, new Wilderness Areas and National Monuments can be designated and can add market premiums to an existing natural amenity. Regional decision makers in the rural West include county commissioners and state leaders who are typically operating under fiduciary mandates. Their historical focus has been on increasing local revenue and taxes, generally done by pushing for greater resource extraction. Our research indicates that a development strategy focused on greater ecosystem protection and environmental quality, as opposed to further resource extraction and damage, can attract new migrants while boosting regional wealth and local taxes.

\section{Conclusion}

The diminished dominance of amenity migration in the 2000s does not mean that amenity migration has ended. Oil and gas booms can obscure amenity migration effects but boom and bust cycles have been the norm for resource extraction in rural areas, leading to fears of dependency on extraction and global markets. While development strategies focused on amenity migration can also experience booms, the infilling associated with amenity migration such as highwage service industries leads to greater sustainability than resource extraction and can become the new economic base (Power and Barrett 2001; Nelson and Beyers 2002). Furthermore, recent research has illustrated that outdoor recreation on protected public lands, a critical attraction for amenity migrants, can be a strong economic development strategy and is likely the most sustainable development option available in rural areas (Hjerpe 2018). Increasing both amenity migration and outdoor recreation development strategies can, at a minimum, provide for a more diverse portfolio of rural economic development strategies.

The first phase of amenity migration in the rural West peaked in the 1990s leading to escalating housing prices and access costs in regions most desirable for their natural amenities. As economic conditions have ripened since the Great Recession, with affordable credit still widely available, a second slower phase of amenity migration is ongoing in the American West. ${ }^{8}$ The second phase of amenity

\footnotetext{
8 While the coronavirus pandemic may lead to economic conditions that hinder amenity migration, it may also push more people from urban to rural areas.
}

migration appears to be more focused on the next best "available" rural areas, those counties with protected areas that are a bit more affordable than iconic Western counties containing communities such as Aspen, Jackson, and Park City. Rural counties with protected areas should expand marketing campaigns highlighting their natural and designated natural amenities to prospective amenity migrants and should understand that resource extraction and amenity development are mutually exclusive options at the local level.

The drastic economic restructuring in the rural West, driven in part by amenity migration, has given rise to communities trying to capture (or market) nonmarket values held by residents and visitors that are focused on public goods such as open space and environmental quality (Marcouiller and Deller 1996; Nelson 2001). Our results reinforce this transition to amenity migration and illustrate that protected areas have a substantial influence on migrant relocation decisions and have become a marketable commodity in their own right. The economic value associated with protected areas and their influence on amenity migration should become a regular component of the discourse that surrounds new proposals for protected areas and new proposals for resource extraction. Currently, these economic values are largely left out of conversations about rural development. County commissioners, conservationists, and regional policymakers would do well to become more fluent in understanding the wealth-attracting influence of protected areas.

Acknowledgements We are very appreciative of comments and suggestions from anonymous reviewers. We acknowledge and thank Leah Dunn for spatial data collections and maps. We thank Susan Fox, Richelle Winkler, Jocelyn Aycrigg, and Paul Jakus for assistance. This research was partially funded by the US Department of Agriculture (17-CS-11221639-142).

\section{Compliance with Ethical Standards}

Conflict of Interest The authors declare that they have no conflict of interest.

Publisher's note Springer Nature remains neutral with regard to jurisdictional claims in published maps and institutional affiliations.

\section{References}

Abrams JB, Gosnell H, Gill NJ, Klepeis PJ (2012) Re-creating the rural, reconstructing nature: an international literature review of the environmental implications of amenity migration. Conserv Soc 10(3): 270

Anselin, L, Bera, AK (1998). Spatial dependence in linear regression models with an introduction to spatial econometrics. In: Ullah A, Giles D (eds) Handbook of applied economic statistics. CRC Press, New York, p237-290 
Aycrigg JL, Davidson A, Svancara LK, Gergely KJ, McKerrow A, Scott JM (2013) Representation of ecological systems within the protected areas network of the continental United States. PLoS ONE 8(1):e54689

Belsley DA (1991) A guide to using the collinearity diagnostics. Computer Sci Econ Manag 4(1):33-50

Beyers WB, Nelson PB (2000) Contemporary development forces in the nonmetropolitan West: New insights from rapidly growing communities. J Rural Stud 16(4):459-474

Carlino GA, Mills ES (1987) The determinants of county growth. J Reg Sci 27(1):39-54

Charnley S, Donoghue EM, Moseley C (2008) Forest management policy and community well-being in the Pacific Northwest. J For 106(8):440-447

Cook AK (1995) Increasing poverty in timber-dependent areas in Western Washington. Soc Nat Resour 8:97-109

Cromartie JB, Wardwell JM (1999) Migrants settling far and wide in the rural West. Rural Dev Perspect 14:2-8

Dearien, C, Rudzitis, G, Hintz, J (2005). The role of wilderness and public land amenities in explaining migration and rural development in the American Northwest. In: Green GP, Deller SC, Marcouiller DW (eds) Amenities and Rural Development: Theory, Methods and Public Policy. Edward Elgar Publishing, Massachusetts, p113-128

Deller SC, Tsai TH, Marcouiller DW, English DB (2001) The role of amenities and quality of life in rural economic growth. Am J Agric Econ 83(2):352-365

Duffy-Deno KT (1998) The effect of federal wilderness on county growth in the intermountain western United States. J Regional Sci 38(1):109-136

Eichman H, Hunt GL, Kerkvliet J, Plantinga AJ (2010) Local employment growth, migration, and public land policy: evidence from the Northwest Forest Plan. J Agric Res Econ 35(2):316-333

Elhorst JP (2014) Spatial econometrics: from cross-sectional data to spatial panels. Springer, Heidelberg, p 480. Vol. 479

Frentz IC, Farmer FL, Guldin JM, Smith KG (2004) Public lands and population growth. Soc Nat Resour 17(1):57-68

Galston WA, Baehler KJ (1995) Rural development in the United States: connecting theory, practice, and possibilities. Island Press, PO Box 7, Dept. 2PR, Covelo, CA, 95428

Garber-Yonts, BE (2004). The economics of amenities and migration in the Pacific Northwest: review of selected literature with implications for national forest management. Gen. Tech. Rep. PNW-GTR-617. US Department of Agriculture, Forest Service, Pacific Northwest Research Station. Portland, OR. 48 p, 617

Gelman, A, \& Hill, J (2006). Data analysis using regression and multilevel/hierarchical models. Cambridge university press

Graves PE, Linneman PD (1979) Household migration: theoretical and empirical results. J Urban Econ 6(3):383-404

Green GP (2001) Amenities and community economic development: Strategies for sustainability. J Reg Anal Policy 31(2):61-76

Green, GP, Deller, SC, \& Marcouiller, DW (Eds.). (2005). Amenities and rural development: theory, methods and public policy. Edward Elgar Publishing

Hand MS, Thacher JA, McCollum DW, Berrens RP (2008) Intraregional amenities, wages, and home prices: the role of forests in the Southwest. Land Econ 84(4):635-651

Headwaters Economics. 2014. Migration and population trends in the West vary by county type. https://headwaterseconomics.org/ economic-development/trends-performance/migration/

Headwaters Economics. 2015. Three Wests: the impact of access to markets on economic performance in the West. https://headwa terseconomics.org/dataviz/three-wests/

Hjerpe EE (2018) Outdoor recreation as a sustainable export industry: A Case Study of the Boundary Waters Wilderness. Ecol Econ 146:60-68
Hjerpe E, Holmes T, White E (2017) National and community market contributions of Wilderness. Soc Nat Resour 30(3):265-280

Hjerpe E, Kim YS, Dunn L (2016) Forest density preferences of homebuyers in the wildland-urban interface. For Policy Econ 70:56-66

Holmes FP, Hecox WE (2004) Does wilderness impoverish rural regions. Int J Wilderness 10(3):34-39

Howe J, McMahon E, Propst L (1997) Balancing Nature and Commerce in Gateway. Communities Island Press, Washington, DC

Izón GM, Hand MS, Fontenla M, Berrens RP (2010) The economic value of protecting inventoried roadless areas: a spatial hedonic price study in New Mexico. Contemp economic policy 28 (4):537-553

Izón GM, Hand MS, Mccollum DW, Thacher JA, Berrens RP (2016) Proximity to natural amenities: a seemingly unrelated hedonic regression model with spatial Durbin and spatial error processes. Growth change 47(4):461-480

Jakus PM, Akhundjanov SB (2019) The Antiquities Act, national monuments, and the regional economy. J Environ Econ Manag 95:102-117

Kruger LE, Mazza R, \& Stiefel M (2008). Amenity migration, rural communities, and public land. In: Donoghue E and Sturtevant, E (eds) Forest community connections: Implications for research, management, and governance, Resources for the Future, New York, 127-142

LeSage JP (2014) What regional scientists need to know about spatial econometrics. Rev Regional Studies 44:13-32

Lorah, PA (2000). Population growth, economic security, and cultural change in wilderness counties. In: McCool, Stephen F.; Cole, David N.; Borrie, William T.; O'Loughlin, Jennifer, comps. Wilderness science in a time of change conference-Volume 2: Wilderness within the context of larger systems; 1999 May 23-27; Missoula, MT. Proceedings RMRS-P-15-VOL-2. US Department of Agriculture, Forest Service, Rocky Mountain Research Station, Ogden, UT. p. 230-237 (Vol. 15)

Lorah P, Southwick R (2003) Environmental protection, population change, and economic development in the rural western United States. Popul Environ 24(3):255-272

Marcouiller, DW, Clendenning, G (2005). The supply of natural amenities: moving from empirical anecdotes to a theoretical basis. In: Green GP, Deller SC, Marcouiller DW (eds) Amenities and rural development: Theory, methods and public policy. Edward Elgar Publishing, Massachusetts, p6-32

Marcouiller DW, Deller SC (1996) Natural resource stocks, flows, and regional economic change: seeing the forest and the trees J Reg Anal Policy 26, 95. https://doi.org/10.22004/ag.econ.130431

Mather AS (2001) Forests of consumption: postproductivism, postmaterialism, and the postindustrial forest. Environ Plan C 19 (2):249-268

McGranahan, DA (1999). Natural amenities drive rural population change. https://doi.org/10.22004/ag.econ.33955

Nelson PB (2001) Rural restructuring in the American West: Land use, family and class discourses. J Rural Stud 17(4):395-407

Nelson PB, Beyers WB (2002) Using economic base models to explain new trends in rural income. Growth Change 29 (3):295-318

O'Brien RM (2007) A caution regarding rules of thumb for variance inflation factors. Qual Quant 41(5):673-690

Power TM (1991) Ecosystem preservation and the economy in the Greater Yellowstone area. Conserv Biol 5(3):395-404. https:// doi.org/10.22004/ag.econ.130431

Power TM (1996) Lost landscapes and failed economies: the search for a value of place. Island Press, Washington, DC, Vol. 38

Power, TM (2005). The supply and demand for natural amenities: an overview of theory and concepts. In: Green GP, Deller SC, Marcouiller DW (eds) Amenities and rural development: Theory, 
methods and public policy. Edward Elgar Publishing, Massachusetts, p63-77

Power, TM, Barrett, R (2001). Post-cowboy economics: Pay and prosperity in the new American west. Island Press, Washington

Rasker R (1993) Rural development, conservation, and public policy in the Greater Yellowstone Ecosystem. Soc Nat Resour 6 (2): $109-126$

Rasker R (2006) An exploration into the economic impact of industrial development versus conservation on western public lands. Soc Nat Resour 19(3):191-207

Rasker R, Gude PH, Delorey M (2013) The effect of protected federal lands on economic prosperity in the non-metropolitan West. J Reg Anal Policy 43(1100-2016-90117):110

Rasker R, Gude PH, Gude JA, Van den Noort J (2009) The economic importance of air travel in high-amenity rural areas. J Rural Stud 25(3):343-353

Rickman, DS, Wang, H (2018). Whither the American West? Natural Amenities, Energy and Nonmetropolitan County Growth. MPRA Paper. https://mpra.ub.uni-muenchen.de/id/eprint/90078

Roback J (1982) Wages, rents, and the quality of life. J Political Econ 90(6):1257-1278

Robbins WG (1994) Colony and empire: The capitalist transformation of the American West. University of Kansas Press, Lawrence

Rudzitis, G (1996). Wilderness and the changing American West. John Wiley and Sons, New York

Rudzitis G (1999) Amenities increasingly draw people to the rural west. Rural Dev Pers 14:9-13

Rudzitis G, Johansen HE (1991) How important is wilderness? Results from a United States survey. Environ Manag 15(2):227-233

Rudzitis G, Johnson R (2000). The impact of wilderness and other wildlands on local economies and regional development trends. In: McCool, SF,
Cole, DN, Borrie, WT, O’Loughlin, J, comps (eds) Wilderness science in a time of change conference-Volume 2: Wilderness within the context of larger systems; 1999 May 23-27; Missoula, MT. Proceedings RMRS-P-15-VOL-2. US Department of Agriculture, Forest Service, Rocky Mountain Research Station, Utah, 14-26

Rudzitis G, Streatfeild RA (1993) The importance of amenities and attitudes: A Washington example. J Environ Syst 22 (3):269-277

Shumway JM, Otterstrom SM (2001) Spatial patterns of migration and income change in the Mountain West: the dominance of servicebased, amenity-rich counties. Prof Geogr 53(4):492-502

Sjaastad LA (1962) The costs and returns of human migration. J Political Econ 70(5, Part 2):80-93

Ullman EL (1954) Amenities as a factor in regional growth. Geogr Rev 44(1):119-132

U.S. Geological Survey, Gap Analysis Program (GAP). 2016. Protected Areas Database of the United States (PAD-US), version 1.4 Combined Feature Class. https://gapanalysis.usgs.gov/padus/ data/download/

Winkler, RL (2010). Rural destinations, uneven development, and social exclusion (Unpublished doctoral dissertation). University of Wisconsin-Madison, Madison, WI

Winkler R, Field DR, Luloff AE, Krannich RS, Williams T (2007) Social landscapes of the inter-mountain West: a comparison of 'old West'and 'new West'communities. Rural Sociol 72 (3):478-501

Winkler R, Johnson KM, Cheng C, Beaudoin J, Voss PR, and Curtis KJ (2013). Age-Specific Net Migration Estimates for US Counties, 1950-2010. Applied Population Laboratory, University of Wisconsin- Madison. Web. [2/16/18]. http://www.netmigration. wisc.edu/ 